\title{
ERRORS ON ORAL PRODUCTION MADE BY ENGLISH DEPARTMENT STUDENTS IN MICROTEACHING CLASS AT UNIVERSITAS MUHAMMADIYAH SURAKARTA
}

\author{
Rismanita Ayu Eka Saputri \\ English Department, School of Teacher Training and Education \\ Universitas Muhammadiyah Surakarta \\ rismanitaayueka@gmail.com
}

\begin{abstract}
The objectives of this research are to describe the types of error, to analyze the frequency of error and to describe the source of error in oral productions made by English department students in microteaching class at Universitas Muhammadiyah Surakarta. The type of this study is descriptive qualitative research. The data of this research are utterances containing errors taken from Microteaching video. The data collection technique of this research is documentary study. There are 289 utterances containing error. The writer uses descriptive qualitative technique to analyze the data. The writer uses theories from Clark and Clark, Dulay, Burt and Krashen and also Selinker to analyze the error. In the result of this study, the writer divided types of error into three classifications. They are speech error, morphological error, and syntactical error. Speech error $(80,28 \%)$, in speech error divided into seven types, they are: filled pause $(39,5 \%)$, repeats $(18,34 \%)$, silent pause $(10,73 \%)$, stutters $(6,57 \%)$, interjection $(2,08 \%)$, correction $(1,73 \%)$, slip of tongue $(1,38 \%)$. Morphological $(13,84 \%)$ in morphological error divided into three types, they are: Omission of Bound morpheme $\{-\mathrm{s}\}$ as plural marker $(2,77 \%)$, pronunciations $(8,30 \%)$, vocabulary $(2,77 \%)$. Syntactical error $(5,88 \%)$, syntactical error divided into four types, they are: omission of modal \{will\} $(1,38 \%)$, omission of preposition $(1,38 \%)$, question construction $(1,38 \%)$, incorrect word selection $(1,73 \%)$. The sources of error are cognitive reason, psychological reason and social reason.
\end{abstract}

Keywords: oral production, error, Microteaching, English students

\begin{abstract}
ABSTRAK
Penelitian ini bertujuan untuk mendeskripsikan tipe-tipe kesalahan, menganalisis frekuensi kesalahan, dan mendeskripsikan sumber kesalahan yang diproduksi oleh mahasiswa Pendidikan Bahasa Inggris di kelas Microteaching Univeritas Muhammadiyah Surakarta. Kajian ini tergolong penelitian deskripstif kualitatif. Data penelitian ini adalah tuturan yang berisi kesalahan mahasiswa yang terekam dalam video microteaching. Teknik pengumpulan data adalah studi dokumentasi. Ada 289 tuturan yang tergolong kesalahan tuturan. Penulis menggunakan teknik deskriptif kualitatif untuk menganalisis data. Teori yang digunakan dalam penelitian ini mengacu pada teori Clark dan Clark, Dulay, Burt, dan Krashen, serta Selinker untuk menganaisis kesalahan. Tipe-tipe kesalahan yang ditemukan dalam kajian ini dibagi ke dalam tiga kelompok. Kesalahan yang ditemukan adalah kesalahan tuturan, kesahalan morfologis, dan kesalahan sintaksis. Kesalahan tuturan (80,28\%) dibagi menjadi tujuh bagian, yaitu filled pause (39,5\%) repeats $(18,34 \%)$, silent pause $(10,73 \%)$, stutters $(6,57 \%)$, interjection $(2,08 \%)$, correction $(1,73 \%)$, slip of tongue (1,38\%). Kesalahan morfologis (13,84\%) dibagi menjadi tiga tipe, yaitu omission
\end{abstract}


of bound morpheme $\{-s\}$ sebagai penanda plural (2,77\%), pronunciations $(8,30 \%)$, vocabulary (2,77\%). Kesalahan sintaksis (5,88\%) dibagi menjadi empat tipe, yaitu omission of modal (1,38\%), omission of preposition (1,38\%), question construction (1,38\%), dan incorrect word selection (1,73\%). Sumber kesalahan adalah factor kognitif serta alasan psikologis dan social.

Kata Kunci: produksi tuturan, kesalahan, Microteaching, mahasiswa pendidikan bahasa Inggris

\section{INTRODUCTION}

Universitas Muhammadiyah Surakarta is one of many Islamic Universities in Indonesia. Universitas Muhammadiyah Surakarta is located in Solo City, Central Java. Universitas Muhammadiyah Surakarta has twelve faculties, the students of the university can choose one of many faculties. Teacher Training is one of twelve faculties and Department of English Education is one of departments in the faculty of Teacher Training and Education. In English Department, students should follow the practice of teaching learning process. For example is in Microteaching class, the goal of Microteaching are to give confidence, support, and feedback to students, by letting the students to try out among their friends. As many as 16 students participate in Microteaching class. One person takes the turn as a teacher, and others as students.

The students in the Microteaching class have produced speech spontaneously. In producing speech, the students often make errors in their speaking. The students sometimes hesitate or stop in the middle of sentence for a moment to think the appropriate word be said next. And most of them did not prepare full planning before they speak, especially in spontaneous speech. For the record, speaking is not an easy thing. Error is considered as an inevitable and positive part of that process (Fauziati, 2009:168).

There are many other studies that were conducted before. The first one is Rakhmawati (2011) in her research paper entitled "A psycholinguistic Analysis of Speech Errors Made by Rachel Ray on TV Show". The second is a research conducted by Fadhila (2013) UMS, in her research paper entitled "Errors in Speaking English Made by Students of English department of Universitas Muhammadiyah Surakarta”. The third is a research conducted by Wijayanti (2013) UMS, in her research entitled "Speech Errors in a Talk Show Program of Metro TV Face to Face with Desi Anwar Broadcasted in January to June 2012". The four is done by Ilmiani (2014) UMS, in her research entitled "Error in Oral Production Made by English Department Students of Universitas Muhammadiyah Surakarta". The fifth research is conducted by Saad (2014) University Kuala Lumpur British Malaysian institute, in his research paper entitled "Error Analysis in Role-Play Presentation among Less Proficient L2 Malaysian learners". In this research, the writer uses some related theories. They are:

\section{Interlanguage}

Interlanguage coined by Selinker (1977). According to Fauziati (2009:157), interlanguage is a study on the language of the second language learners. These terms refer to (1) Transitional Competence, (2) Idiosyncratic Dialect, (3) Approximative System. Interlanguage divided into three concept, they are: Adjemian's concept, Selinker's concept, Tarone's concept.

\section{Error analysis}

According to Ellis 1994, Identification of error is defined as deviation from target language form. According to Dulay, Burt and Krashen (1982) error can classify into many types. The first Language components include phonology (pronunciation), syntax and morphology (grammar), 
semantics and lexicon (meaning and vocabulary). The second surface taxonomy strategy is divided into four types, namely: Omission, Addition, Misformation, Misordering.

\section{Speech error}

According to Fromkin (1968) and Green (1969) in Fromkin (1973: 215) "Speech error have been investigate in attempts to show the reality of phonological units and rules, and the relationship between linguistic competence and performance. According to Clark and Clark (1977: 263) in Fauziati (2009), there are many kinds of errors. Those are: 1) Silent pause, 2) Filled pause, 3) Repeats, 4) Unrestricted, 5) Retraced, 6) Correction, 7) Interjection, 8) Stutters, 9) Slip of tongue.

The objectives of this research are as follows. (1) To describe the types of errors made by English Department Students in Microteaching class at UMS. (2) To describe the frequency of errors made by English Department Students in Microteaching class at UMS. (3) To describe the sources of errors made by English Department Students in Microteaching class at UMS.

\section{RESEARCH METHOD}

In this research, the writer uses descriptive qualitative research. The writer uses descriptive qualitative is to describe the type of error, the frequency of error, and the sources of error in oral production made by English Department Students in Microteaching Class at UMS, also to make the conclusion about this research.

The objects of the research are the utterances containing errors by the students of English Department of UMS in Microteaching class in 2014/2015 academic years. The data of this research are in the form of utterances containing errors taken from transcription of Microteaching video. The writer takes the data from the video of Microteaching class especially in class $i$. The numbers of the data are 15 videos of Microteaching.

The writer uses documentary study in collecting the data. The writer collects the data through following techniques: the writer collects the video from the lecturer in microteaching class, the writer watches, observes and make the script from the video, the writer listens, read the script and identifies the data that include to utterance containing errors, the writer selects the data based on the type of errors, the writer classifies the type of errors in speaking English. In analyzing the data the writer uses descriptive qualitative technique as follows: data reduction and data display.

\section{FINDINGS}

In this part, the writer discusses the research finding and presents the answer of the problem statement. In research finding, the writer presents classification of the types of error, the frequency of each type and the last is the sources of error.

\section{Types of Error}

The writer classified the data based on the theory of type of speech errors suggested by Clark and Clark in 1977.

\section{a. Speech Error}

In this research the writer just found seven types of nine types of speech error. The first is filled pause. Filled pause occurs when the speaker tries to find the next word when they speech and produce speech sound such as um, uh, er, aa, etc. The researcher found 144 utterances containing filled pause from the video of Microteaching. The example of the data is "Can you $\mathrm{emm} /$ describe about yourself?" It showed when she used filled pause 
after saying "can you". She made a gap filled by producing sound "emm" while thinking the next words. She continued her speech by utter the right word "describe" after she produced sound "em".

The second is silent pause. Silent pause occurs when the speaker takes a second or more between words. It means the speaker takes silent when they got difficulty to find the next word to say not to takes a breath. In silent pause the writer found 31 utterances. This is an example of silent pause that taken from video of Microteaching class "if you ... (3 second) look yellow light you ... (5 second) mind?". After the word "if you", the student stopped and kept silent for 3 second. Then the student completed the sentence by saying "look yellow light you". After completed the sentence the student stopped again for 5 second, and she continued the sentence by saying "mind". According to the example, the student might got difficulty to find and remember the words "look yellow light you" and the word "mind". The speaker did silent and stopped her speech because her mind was planning and thinking of the next word what she will say.

The third is repeats. The speakers usually repeat one or more word caused they forget to utter the next word, so they repeat the word said before. The researcher found 53 utterances containing repetition in the data. This is an example of the data "From this picture/from this picture who is invited to the party?". It showed that the speaker repeated the word "From this picture" twice until she could continue and found the next word to say.

The fourth is stutters. Stutter occurs when the speaker felt nervous or did not mastery the material. The writer found 19 utterances containing stutters of errors such as "I have a video $a$ - $a$ - are you ready to study?". The student in the example actually was planning the next word to say. But, they got difficulty when she uttered "are", before uttering the word "are" she repeated " $a$ " twice before uttering "are".

The fifth is interjection. Interjection means the speaker stops for a while to get next intended word. In interjection the speaker usually produced the sound such as "oh, yak, well, etc when they got the intended word. The writer found 6 utterances containing interjection from Microteaching class. For example is "Yak, amm I think enough". In this example the student might feel confused and got trouble to close her meeting. She was silent at a moment to think the next word. So, she exclaims "yak" when she remembered the word "I think enough" to close that meeting.

The sixth is correction. Correction is common types of speech error. Correction contains an explicit correction such as "I mean, rather, sorry". When the speaker used explicit "I mean, rather and sorry" automatically the listener knew that the speaker made an error and tried to correct it by using the explicit word. In the data of error in Microteaching class, the writer found 4 utter that containing correction. This is an example of correction taken from video of Microteaching class "If you on the street do you like the $e h$, do you look a red light?" This example showed that the student corrected her speech by using explicit word "eh" then continued the speech with corrected word "do you look a red light?".

The last is slip of tongue. Slip of tongue defined as unintended, non-habitual deviation from a speech plan (dell in Poulise, 1999: 1, in Fauziati, 2009: 78). The writer found 5 utterances that containing of Slip of tongue. For example "Can you read the praksis . . . practice?". The student made slip when says the word "practice", she made slip and say the word "practice" to be "praksis". 


\section{b. Morphological Error}

Morphological error means the structure of words, how words are formed, and how the parts fit together. In morphological errors the writer finds 3 types of morphological error. The first is omission of bound morpheme $\{-\mathrm{s}\}$ as plural marker. Omission is a type of error which is characterized by absence of an item that must appear in well-formed utterances. As an example in grammatical word such as noun and verb inflection (-s, -ed, -ing). In the data, the writer found eight utterances that contain omission of bound morpheme $\{-\mathrm{s}\}$ as plural marker. For example, "I have some picture things in the bedroom". The speaker made a grammatical error when she uttered "some picture". It was clearly un-corrected form, because indefinite numeral adjective "some" should be followed by noun $(\mathrm{N})$ and morpheme $\{$-s/-es $\}$. Word picture was as plural form. So, the corrected sentence was "I have some pictures things in the bedroom".

The second is pronunciation. Pronunciation means production of sounds that we use to make a meaning when speaking. In Video of Microteaching class, the writer found 23 utterances containing of error when produced sound or error in pronunciation. This is one example of 23 utterances of error in pronunciation "Thanks for coming and see you next week". The student made an error when she uttered the word "coming". The word "coming" should be pronounced as [' $\mathrm{k} \wedge \mathrm{mIn}$ ], but she uttered it as ['kımen]. It showed that she made an error by using vocal sound [e] rather than [I] when she uttered the word "coming".

The third is vocabulary. According to Selinker (1997) in Fauziati (2009) the learners sometimes utilize code switched from English into Indonesia. The writer found 8 utterances containing vocabulary error. This is an example "Yah, a pake yang putri Indonesia". The mother tongue in certain condition such as in the Microteaching class could influence the speaker to make an error, so the student used "Yah, a pake yang putri Indonesia", to replace "Putri you may use Indonesian".

\section{c. Syntactical Error}

Syntactic is relating to the rules of language. Such as, word, phrase, clause and sentence. In syntactical errors the writer finds 4 types of morphological error. The first is omission of modal \{will\}. Modal is a verb that combines with another verb to indicate mood or tense. Modal must be followed by verb one (V1), modal has no -s/es, -ing, to and -ed. The writer found 4 utterances containing omission of modal from the video of Microteaching class. This is one example of 4 utterances "I ( . . .) playing the video, if you don't crowded". Based on the example above, the students made an error before he uttered the word "playing". Before the word "playing" she should use modal "will" and the word "playing" should be uttered as "play". Because modal "will" must followed by V1 not Ving. And in the words “don't crowded" should utter as "don't be crowded".

The second is omission of preposition. Preposition is the word that use before noun or pronoun. It is used to show the relation between noun and pronoun with other word in a sentence. The example of preposition is in, on, at, from, etc. In the data the writer found 4 utterances containing omission of preposition in microteaching class. For example "(. . .) Monik group who will explain?". It showed that the student had an error before she uttered the word "Monik". She should use the preposition "from" or "to" before uttering the word "Monik". And the word "Monik" might add \{ $s\}$ to show if the group was come from hers. So, the correct word was" from Monik's group who will explain?" or "To Monik's group who will explain?". 
The third is question construction. In question construction the writer found one types of an error. It is "omission of auxiliary verb". Auxiliary verb is the same as modal. It used to make negative sentence and interrogative sentence or questions. The writer found 4 utterances such us “(. . .) You finished students?”. Based on the example, the student did not used auxiliary verb when he says question sentence. He should used auxiliary verb "have" before he uttered the question "you finished students?". It was Incorrect, so, the corrected sentence was "Have you finished students?".

The fourth is wrong in word selection. Wrong in word selection means the speakers got trouble when they choose the word in their spoken. In the data of error, the writer found 4 utterances that containing of wrong in word selection. Such us "Oke, you mention the picture in front of the class, read the picture and look friend". In the example showed if the student got trouble when he choose the word "read" before he uttered the word "picture". He should choose the word "mention" not "read" because the picture cannot to read.

\section{The Frequency of Each Type of Error that Showed by English Department Students in Microteaching Class at UMS}

After analyze the data, the writer found the percentage of the frequency of each types of error. The total of the data are 289 utterances. From the data, the writer does not find all types of speech error. The percentages of the frequency of each types of error are as follows:

\begin{tabular}{|c|c|c|c|}
\hline No & Types of error & $\mathbf{N}$ & $\%$ \\
\hline \multicolumn{2}{|c|}{ Speech Error } & 232 & $80,28 \%$ \\
\hline 1. & Filled Pause & 114 & $39,45 \%$ \\
\hline 2. & Repeats & 53 & $18,34 \%$ \\
\hline 3. & Silent Pause & 31 & $10,73 \%$ \\
\hline 4. & Stutters & 19 & $6,57 \%$ \\
\hline 5. & Interjection & 6 & $2.08 \%$ \\
\hline 6. & Correction & 5 & $1,73 \%$ \\
\hline 7. & Slip of the tongue & 4 & $1,38 \%$ \\
\hline \multicolumn{2}{|c|}{ Morphological Error } & 40 & $13,84 \%$ \\
\hline 1. & $\begin{array}{l}\text { Omission of Bound Morpheme }\{-\mathrm{s}\} \text { as } \\
\text { plural marker }\end{array}$ & 8 & $2,77 \%$ \\
\hline 2. & Pronunciation & 24 & $8,30 \%$ \\
\hline 3. & Vocabulary & 8 & $2.77 \%$ \\
\hline & Syntactical Error & 17 & $5,88 \%$ \\
\hline 1. & Omission of modal $\{$ will $\}$ & 4 & $1,38 \%$ \\
\hline 2. & Omission of preposition & 4 & $1,38 \%$ \\
\hline 3. & Question Construction & 4 & $1,38 \%$ \\
\hline 4. & Wrong in Word Selection & 5 & $1,73 \%$ \\
\hline \multicolumn{2}{|c|}{ Total of the data } & 289 & $100 \%$ \\
\hline
\end{tabular}

\section{The Sources of Error}

There are three possible sources in the process delivering speech that make an error. The first is cognitive reason. Cognitive is the study of mental process, such how the people think, perceive, remember, and learn. In cognitive reason, the student needs brain processing to processing information and the information uttered by speech. For example the students command their friend to describe themselves, "Can you emm/ describe about yourself?". They produce "emm" when they think the next word. After they got intended word, the student continued their speech by saying "describe about your self?". 
The second is psychological reason. In certain condition, the students may produce an error when they speech, such as anxious, nervous, in hurry or other. The students may fell difficult to produce speech. Such as is in Microteaching class, when the students delivering their materials, they may feel nervous. It is because they must stand up in front the other students as a teacher to speech and explain the topic that they get before and they may not master their material yet. For example, "You will/you will aap/you will introduce your self", and "Generic structure of reco-reco recount text". The student made speech error in a one moment there were repeats and filled pause. In the second example, the student made speech error stutters. The students were nervous and might be confused.

The last one is social reason; the relation between the speaker and the listener is the influence to the speaker when the speaker is delivering their speech or material. In this condition, the students may produce a lot of error. Such as, make grammatical error, pronunciation error and slip of tongue. For example, "I hope [hup] you can understand aaa this material". That example showed that the student taken a few second to utter this material by producing sound "aaa", and incorrect pronunciation in the word "hope". In this condition the students feels in under pressure, because they must delivers and explains their material to their friends in a short time and in the same time their lecturer assesses their performance to give score and review about their performance.

\section{DISCUSSION}

In this part the writer discusses the research finding. The writer explains the findings related to the types of error, the frequency of error and the sources of error. The findings of the research would compare with previous study.

There are three classifications from 289 data. First is speech error, the writer does not find all types of speech error, the writer just found seven types of speech error, they are: filled pause, silent pause, repeats, correction, stutters, interjection and slip of tongue. The writer does not found retraced false and unrestricted false from the data of error. Second is morphological, there are omission of Bound Morpheme $\{-\mathrm{s}\}$ as plural marker, pronunciation and vocabulary. Third is syntactical error, there are omission of modal $\{$ will $\}$, omission of preposition, question contraction and wrong in word selection.

The writer will compare this study with the previous study. There is no similarity between this study and all of previous study, there are some differences between them. Although in some previous the writer found the same dominant error namely filled pause, but the percentage is different. The writer found filled pause as the dominant of error in the third and fourth previous study, which is same with this research but different in percentage.

The third previous study which come from Wijayanti, found the filled pause as the dominant error with the percentage $33,41 \%$ and the fourth previous study found 53 utterances filled pause and the percentage is $28,34 \%$. Then the first previous study from Rakhmawati, found the frequency of substitution is $24.16 \%$ as the dominant of error. The second and the fifth previous study use different theory that the dominant is also different. In the second previous study is come from Fahdila, she is uses Clark and Clark, Dulay, Burt and Krashen theories. The top rank of percentage of Fahdila's Work is substitution $27,4 \%$ as dominant of error. Saad who used James theory found utterances containing addition 39.5\%. And the last comes from Rakhmawati as the first previous study. The dominant of this research is substitution. She found $27 \%$ containing substitution.

The writer found 3 sources of error, and the writer determines the sources of error, namely: (1) social reason, (2) psychological reason and (3) cognitive reason. The writer tries to compare this result with the previous researcher. The difference between this study and Fahdila's 
work and Ilmiani's work are they found five sources of error. There are (1) social reason, (2) psychological reason, (3) cognitive reason, (4) interlingual reason and (5) intralingual reason. While in this research the writer found three sources of error, namely: (1) social reason, (2) psychological reason and (3) cognitive reason. The sources of this research are different with the sources from previous study.

\section{CONCLUSIONS}

1. The writer found three kind of error, there are: speech error, morphological error and syntactical error. Speech error classifies into seven types: (1) filled pause, (2) repeats, (3) silent pause, (4) correction, (5) interjection, (6) stutters and (7) slip of tongue. Pronunciation error classifies into three types, namely: (1) omission of Bound Morpheme $\{-\mathrm{s}\}$ as plural marker, (2) pronunciation and (3) vocabulary. Then syntactical error classifies into four types, there are: (1) omission of modal $\{$ will $\},(2)$ omission of preposition, (3) question construction and (4) error in selection word.

2. The frequency of speech error is $80,28 \%$ of speech error, $13,84 \%$ of morphological error, and syntactical error 5,88\%. Speech error classifies into seven types they are, filled pause $(39,45 \%)$, repeats $(18,34 \%)$, silent pause $(10,73 \%)$, stutters $(6,57 \%)$, interjection $(2,08 \%)$, correction $(1,73 \%)$, and slip of tongue ( $1,38 \%)$. In morphological error divided into three types, omission of bound morpheme $\{-\mathrm{s}\}$ as plural marker $(2,77 \%)$, pronunciation error $(8,30 \%)$ and $2,77 \%$ including to vocabulary error. In syntactical error divided into four types, omission of modal \{will\} $(1,38 \%)$, omission of preposition $(1,38 \%)$, question construction $(1,38 \%)$ and wrong in selection word $(1,73 \%)$. From the frequency, the writer assumes the dominant error of this research is speech error especially filled pause.

3. The writer also found the causes that make the utterances become error, there are: (1) cognitive reason, (2) psychological reason and (3) cognitive reason.

As the result, since the writer found 289 error utterances. The writer presumes that the speaker in Microteaching class i of English Department at Universitas Muhammadiyah Surakarta still make a lot error in their speech. Speech error is the error that occurred often, especially in filled pause.

\section{REFFERENCES}

Ellis. Rod. 1994. The Study of Second Language Acquisition. London: Oxford University Press.

Dulay, Heidy. Mariana Burt and Stephen Krashen. 1982. Language Two. New York: Oxford University Press.

Fadhila, Hawa. 2013. Errors in Speaking English made by Students of English Department of Muhammadiyah University of Surakarta. Unpublished Research Paper. Surakarta: Universitas Muhammadiyah Surakarta

Fauziati, Endang. 2009. Psyholinguistcs an Introduction. Surakarta: Era Pustaka Utama 2009. Readings on Applied Linguistics. Surakarta: Era Pustaka Utama.

Fromkin. A. Victoria. 1973. Speech Errors as Linguistic Evidence. Los Angelas: Inuversity of California.

Ilmiani, Dwi. 2014. Errors in Speaking English Made by Students of English Department of Muhammadiyah University of Surakarta. Unpublished Research Paper. Surakarta: Universitas Muhammadiyah Surakarta. 
Poulise, Nanda. 1999. Slip of the Tongue: Speech Errors in First and Second Language Production. (Huebner, Thom and Kees de Bot, Eds). Amsterdam: University of Amsterdam.

Rahmawati, Sulistyo Ayu. 2011. A Psycholinguistic Analysis of Speech Errors made by Rachel Ray on TV Program. Unpublished Research Paper. Surakarta: Universitas Muhammadiyah Surakarta.

Saad, Mohammad Azannee Haji. 2014. "Error Analysis in Role-play Presentations among Less Proficient L2 Malaysian Learners". International Journal of English and Education. Vol.3. No.3. hal 346-355.

Wijayanti, Farida Indri. 2013. Speech Errors in a Talk Show program of Metro TV face to face with Desi Anwar Broadcasted in January to June 2012. Unpublished Research Paper. Surakarta: Universitas Muhammadiyah Surakarta. 